\title{
Professional Preparation and Performance of Preschool Teachers in the Public and Private Schools of Cebu City, Philippines
}

\author{
GLENN R. ANDRIN \\ drandringlenn@gmail.com \\ ORCID No. 0000-0002-3008-5661 \\ JONATHAN O. ETCUBAN \\ joetcuban@gmail.com \\ ORCID No. 0000-0001-8930-6476
}

ANNA KATRINA O. WATIN

akvoaminal_cebu@yahoo.com

ORCID No. 0000-0002-8140-5012

ROBERT MALUYA

drrobert.phd@outlook.com

ORCID No. 0000-0002-8140-5012

EARL DAVE V. ROCHA

earl.uc@gmail.com

ORCID No. 0000-0002-7286-1673

ALMA A. MAULIT

aamaulit@gmail.com

ORCID No. 0000-0002-5600-7338 


\section{ABSTRACT}

The privilege of instruction is the privilege to get to training as well as the opportunity to get training of high quality. Education must be accessible and open additionally adequate and versatile. This study determined the professional preparation and performance of the preschool teachers in public and private schools in Cebu City with the end view of using the findings in designing a Preschool Training Program. The review made utilization of the clear correlational strategy in social affair information from preschool instructors and the school's principals in Cebu City, Philippines. They are advised to answer the questionnaire for teachers and administrators, the performance appraisal form for teachers. The study revealed that the public preschool teachers have less adequate teaching experience while the private preschool teachers have appropriate teaching experience. Additionally, there is a critical distinction in the expert arrangement of the general population and private preschool instructors with the private part of the lead. It was presumed that the general population and private preschool educators have a similar expert arrangement profile and execution. In any case, there is no basic difference in the execution between the overall public and private preschool teachers. The specialists suggest that school overseers ought to direct more in administration preparing on preschool training to enhance the instructional skills of their educators.

\section{KEYWORDS}

Education, professional preparation, performance, descriptive study, Philippines

\section{INTRODUCTION}

Quality education is needed for a nation to become vigorous and able to pursue its desired visions and goals. Its people cannot fulfill their personal and social responsibilities efficiently and effectively if not given quality education. To meet this need, its Long-term Development Plan has for its thrust to make the quality of education as the overriding goal of the educational system (Thom-Otuya, 2012). Aside from other priorities, early childhood care and development are one of its major goals in pursuit of education missions of development (Monsalve, 2016; Maca \& Morris, 2012). The educational performance goal and objectives of the master plan 
state that all children in the Philippines will be provided with early childhood care and development (Barlett et al., 2016; Manuel \& Gregorio, 2011). This bold move was believed to be motivated by the researched-based concept that early childhood education improves to a great extent the preparations of the child for subsequent formal schooling (Taylor, 2016).

In response to the need to pursue the goals embodied in the MediumTerm Philippine Development Plan, the then Department of Education (DepEd) has provided a limited basis based on the currently organized preschool classes through DECS Order no. 60 s. 1993. More recently, the DepEd issued a Memo No. 488, urged public school officials to participate in a school library cum preschool classroom project of DepEd in partnership with the Aklat, Gabay, ArugatungosaPag-angat at Pag-asa (AGAPP) foundation (Luz, 2009). Educators need to collaborate on various projects that will continue the goal of reaching all five-year-old children and to provide them with the much-needed learning environment and experiences (Bonetti et al., 2016; Twyman, 2016; Visse, 2016).

In August 2010, the DepEd and AGAPP Foundation launched the School Libraries cum Preschool Classroom with the construction of onestory building furnished as the school library, which will be utilized as kindergarten classroom with accompanying age-appropriate instructional materials. According to DepEd Secretary, there is a need to facilitate teacher training and school staff development with a focus on early childhood care and development and family literacy if early childhood education in the Philippines is to be successful (Lapus, 2008; Bernardo \& Garcia, 2006).

In this regard, school administrators throughout the country were enjoined to conduct a survey of current preschool and to allow schools to establish preschool classes if only to provide early childhood stimulation needed during the children's formative years. It is indeed a remarkable decision that the government has taken initial steps to institutionalize early childhood development even on just a limited basis.

Since administration, supervision, and teaching preschool classes present a distinct structure and strategy from that of teaching and supervision in the elementary school, the manner in which these are implemented is a very sensitive issue. How well would the preschool teachers deliver education to their clientele since the majority of them are not graduates of the Bachelor of Elementary Education major in Early Childhood Education? This pinpoints to the issue on the quality of performance. The next issue would be on "How professionally qualified are these preschool teachers? 
One must bear in mind that Preschool teaching requires specialized training. Teachers must be alert and creative enough to implement games and plays suited to the nature of preschoolers. The strategies of teaching are also entirely different from their previous training; the number of hours was insufficient to declare that these teachers are already competent enough to teach preschoolers. The same is true with their school administrators. The teachers and administrators in public and private schools are placed in a quandary.

The prevailing situation has prompted the researchers to delve into determining the professional preparation and performance of preschool teachers teaching in public and private schools offering preschool education in the city of Cebu with the view of proposing a Preschool Training program intended for preschool teachers.

\section{FRAMEWORK}

This study is anchored on Richter's (2004) Social Determinants of Early Child Development Theory. As indicated by him, there are basic standards of ideal physical, socio-passionate, and psychological/dialect advancement that apply to every single person crosswise over societies and ethnic foundations. Social determinants assume a fundamental part in the early periods of origination, pregnancy, and post-natal times of kids' improvement (Magg Sensitive periods in the brain and biological development start prenatally and continue throughout childhood and adolescence (Lupien et al., 2009). How much these methods provoke big change depends on the qualities of actuation, support, and nurturance in the social circumstances in which adolescents live, learn and create (Irwin et al., 2007). By school age, change has been affected by segments at three levels of society: family, neighborhood, and the broader societal level. Money related slants in prosperity over the life course begin as budgetary slants in early child progression (Marmot and Bell, 2012; Doyle et al., 2009).

Today, kindergarten education still shows the characteristic trends suggestive of its historical background. At the same time, it has also adopted modification in the direction of newer precise movements in psychology and education. In the Asia-Pacific district, the pattern was towards a sound thankfulness and advancement of the significance of early adolescence care and instruction (ECCE) (Vesely, 2013; Kaga et al., 2010). The part of the ECCE tremendously affects forming the character of kids less than 
six years old by encouraging a youngster's full advancement potential at an early age; key encouraging a smooth move from home to class; and by distinguishing early indications of the requirement for individual intercession (Yunusa, 2016).

UNESCO further reported that all the countries within the Asia-Pacific region, government sponsored programs for early childhood population exists (Eichner et al., 2011). Although there are variations in both design and quality, generally, the programs are aimed at developing the child's mental readiness for school and frequently incorporate reading and writing (Early et al., 2007). Recent aspects related to the physical, emotional and social development of the child have been added to the programs in many countries. One such feature is the inclusion of some forms of health care. This includes medical care centers such as municipal care health $(\mathrm{MCH})$ centers, which provides health checks and vaccinations for young children. These centers, however, seldom incorporate educational programs. In the developing countries, the government ministries of public health, social welfare, and education or internal home affairs initiate ECCE programs (Yoshikawa \&Kabay, 2015). Preschools have been developed through commercial ventures or private foundation initiatives. They focus on matters about school entry competence, such as the introduction of reading, writing, and foreign language skills.

Kindergarten Education has casual and foreboding begin with private mentoring among offspring of well-to-do families (Kolker, 2011). The motivation behind this sort of pre-instruction at home was to plan youngsters immediately for more propelled work. Introductory endeavors to give kindergarten training were Mujeres, which started the association of kindergarten schools in the Philippines. As more non-public schools and universities opened, enthusiasm for pre-training developed. The schools built up then were alluded to as "child classes." The preschool classes began casual prevailed by the "at home air." Classes, however, were deficiently outfitted with the absence of workforce exceptionally prepared to instruct the preschoolers. Back then, kindergarten schools worked as free units when allowing first kindergarten classes were then required to private foundations. Afterward, more noteworthy impulse on kindergarten classes was offered in regular government schools in their research center schools, where educators were given preparing in showing preschool youngsters.

The preschool children could increase valuable learning knowledge amid an early stage, which to them is a significant time in their lives. Availability 
for getting the hang of, perusing, composing, numbering or all that could be utilized as establishments of a subject at an early age are instructed at this level. Preschool likewise offer experiences and social collaborations with companions in a controlled domain.

The curriculum of kindergarten as one that stresses self-activity, utilizing games and play (Haq et al., 2015). It has provisions for developing readiness for more exact types of learning such as building an essential vocabulary for reading in the primary grades. It emphasizes social and emotional adjustments by selecting and organizing experiences so that the child is made sensitive to the better aspects of culture. Its instructions are based on the child's needs and interests rather than on force and compulsion. It also has some provisions for the promotion of closer relationships among the children, and between the child and her parents and their teachers and the community. It has also provided for a greater variety of activities such as housekeeping, block building, storytelling, sand and water play, painting and coloring. There is an alteration between quiet and vigorous activities for a small and large group of children snacks and rest periods are provided.

The kindergarten curriculum consists of skills/adjectives and similar activities mapped out in daily plans. It aims to develop the social, motor and other readiness skills of pupils before formally undergoing the Grade one work. The activities are made up mostly of games, songs, movements, stories and other play activities. These were carefully selected to make children feel that schooling can be pleasant and enjoyable. The teacher is free to adopt the activities which she believes will carry the objectives to meet the needs of the pupils. As early youth, educational modules models and rules were upgraded all through time, nations' initial training educational programs likewise influenced by the advancements and improvements in the field as needs are. The Philippines also had gone through many ways regarding early childhood curriculum.

The importance of preschool education scientifically has proven that a child becomes a better learner when he has a Preschool Education. Children with Preschool education not only learn faster, but they also become better achievers. From an economic point of view, when children have had preschool experience before entering Grade One, there are fewer incidences of dropouts. The positive reinforcement they receive as young children about school, strengthen their desire to resolve to stick it out until college. 


\section{OBJECTIVES OF THE STUDY}

This study determined the professional preparation and performance of the preschool teachers in public and private schools in Cebu City, Philippines with the end view of using the findings in designing a Preschool Training Program. Specifically, the study determined the: 1) Profile of the respondents; 2) Performance of the preschool teachers in the context of Instructional Competencies, Professional and Personal Characteristics, and Punctuality and Attendance; 3) Significant difference of performances among preschool teachers; and 4) Significant relationship between profile and performance variables of preschool teachers.

\section{METHODOLOGY}

The review made utilization of the graphic correlational strategy to two gatherings of respondents. One group is the teachers teaching preschoolers whose performance and professional preparation are to be established in the study. The other group is the principals of these teachers whose opinions and ratings solicited since they are the direct supervisors of these teachers.

Since there are many schools in the City of Cebu, the researchers resorted to the convenient purposive sampling technique in the selection of respondents as provided by DepEd office in Cebu City. In the use of this technique, the public schools are grouped according to size. Three big, three medium and three small-sized districts are selected through a drawa-lot method. In search of the three selected districts, the schools are also grouped according to size. Out of the groups, two schools are selected meaning in each district there shall be two big, two medium and two small schools. The same process of selection will be used in the selection of schools in the private schools. The schools offering preschools are grouped into: universities, colleges, complete preschool, elementary and high school; preschool up to elementary school preschool only. In these groupings, the research selected all the preschool teachers in each school.

There are 18 public schools and 18 private schools. Fortunately, the number of preschool teachers taken as respondents, which is 38 and 18 principals, coincided exactly in number with the 18 private schools regarding some respondent principals and respondent preschool teachers. A total of 36 Heads of schools and 76 preschool teachers are the sources of data for this investigation. This number is good enough because it is not easy to request every principal to rate their teachers with the new performance rating form used by the public schools and modified to conform to a similar 
performance evaluation form to be filled up by the Private School principals.

Cebu City, popularly known as the Queen City of the South is favorably chosen as the venue for this research study. Hailed as one of the most friendly cities in the world and one of the growing metropolises in the Philippines. Cebu City offers a conducive environment for the study because of the availability and dominance of preschools, both in the private and public setting. Cebu City metamorphosed in more ways than one, but always for the better. Being the first and the oldest city in the country, she is credited with having the oldest school aside from being the cradle of Christianity in the Far East.

Cebu's historical first is a merit which can be related to education, for after all education leads to facts. The city's growth attributes to the growth of her people who developed themselves into artisans, business people, merchants, and educators. How they became as such would undoubtedly give us intimate knowledge of where they have enriched themselves with knowledge and skills, a fact enriched by the number of schools mushrooming the city from preschools to colleges and universities, attracting not only students from the metropolis but neighboring provinces from Visayas and Mindanao. Thriving in business commerce and trade, the population grew in immense proportion from local people to immigrant through assuming growth for educational learning and development.

The instruments for a gathering of data were: (a) questionnaire for teachers' (b) questionnaire for principals and (c) performance appraisal form for teachers. The survey for teachers has two main parts, namely: Personal profiles where the following information are asked: sex age, employment status, and professional licenses; and professional preparation where their highest educational attainment, major field of specialization. In-service and pre-service training related to Preschool and length of teaching experience related to preschool. The questionnaire for principals contains items based on the criteria for rating. The performance appraisal for teachers used by the public and private schools in assessing the performance of the teachers toward the end of the school year. These are documents filed at the office of the principals.

The questionnaires for teachers and administrators were validated to a group of preschool teachers and their administrators who are not included in the study. The result was analyzed and evaluated. Some of the questions were revised, discarded and or changed depending on the recommendation of the review committee. The Performance Appraisal Report was no 
longer to validated. This is an instrument being used by the public-school administrators in rating their teachers throughout the Philippines. This was already validated before it was thrown to the field for implementation. The gathered data were treated using frequency, simple percentage, weighted mean, Chi-square test of independence, Pearson $r$, and t-test.

\section{RESULTS AND DISCUSSION}

Table 1. Profile of the Respondents

\begin{tabular}{|c|c|c|c|c|c|c|}
\hline \multicolumn{7}{|c|}{$(n=112)$} \\
\hline & \multicolumn{2}{|c|}{$\begin{array}{l}\text { Public Schools } \\
\qquad(n=56)\end{array}$} & \multicolumn{2}{|c|}{$\begin{array}{l}\text { Private } \\
\text { Schools } \\
(n=56)\end{array}$} & \multicolumn{2}{|c|}{$\begin{array}{c}\text { Total } \\
(n=112)\end{array}$} \\
\hline & f & $\%$ & f & $\%$ & $f$ & $\%$ \\
\hline \multicolumn{7}{|l|}{ A. Gender } \\
\hline Male & 1 & 1.79 & 4 & 7.14 & 5 & 4.46 \\
\hline Female & 55 & 98.21 & 52 & 92.86 & 107 & 95.54 \\
\hline \multicolumn{7}{|l|}{ B. Age (in years) } \\
\hline $20-35$ & 18 & 32.14 & 30 & 53.57 & 48 & 42.86 \\
\hline $36-50$ & 16 & 28.57 & 17 & 30.36 & 33 & 29.46 \\
\hline $51-65$ & 22 & 39.29 & 9 & 16.07 & 31 & 27.68 \\
\hline \multicolumn{7}{|l|}{ C. Employment Status } \\
\hline Permanent & 41 & 73.21 & 45 & 80.36 & 86 & 76.79 \\
\hline Probationary & 14 & 25.00 & 11 & 19.64 & 25 & 22.32 \\
\hline Substitute & 1 & 1.79 & 0 & 0.00 & 1 & 0.89 \\
\hline \multicolumn{7}{|l|}{ D. Professional Licenses } \\
\hline Teacher's Exams & 25 & 44.64 & 6 & 10.71 & 31 & 27.68 \\
\hline PBET & 13 & 23.21 & 28 & 50.00 & 41 & 36.61 \\
\hline $\begin{array}{l}\text { Licensure Examinations for } \\
\text { Teachers }\end{array}$ & 18 & 32.14 & 16 & 28.57 & 34 & 30.36 \\
\hline None & 0 & 0.00 & 6 & 10.71 & 6 & 5.36 \\
\hline \multicolumn{7}{|l|}{ E. Educational Attainment } \\
\hline Doctoral Graduate & 9 & 16.07 & 3 & 5.36 & 12 & 10.71 \\
\hline Masters Graduate & 8 & 14.29 & 4 & 7.14 & 12 & 10.71 \\
\hline Masters Units & 22 & 39.29 & 33 & 58.93 & 55 & 49.11 \\
\hline Bachelor in Elementary Education & 14 & 25.00 & 9 & 16.07 & 23 & 20.54 \\
\hline Other Courses & 3 & 5.36 & 7 & 12.50 & 10 & 8.93 \\
\hline
\end{tabular}




\section{F. Major Field of Specialization}

\begin{tabular}{|c|c|c|c|c|c|c|}
\hline Applied Nutrition & 1 & 1.79 & 0 & 0.00 & 1 & 0.89 \\
\hline $\begin{array}{l}\text { Educational Administration \& } \\
\text { Supervision }\end{array}$ & 12 & 21.43 & 4 & 7.14 & 15 & 13.39 \\
\hline Educational Management & 20 & 35.71 & 11 & 19.64 & 31 & 27.68 \\
\hline Educational Technique & 0 & 0.00 & 3 & 5.36 & 3 & 2.68 \\
\hline English & 4 & 7.14 & 11 & 19.64 & 15 & 13.39 \\
\hline Guidance \& Counseling & 5 & 8.93 & 3 & 5.36 & 8 & 7.14 \\
\hline Home Economics & 2 & 3.57 & 3 & 5.36 & 2 & 3.57 \\
\hline Math & 2 & 3.57 & 3 & 5.36 & 5 & 4.46 \\
\hline Physical Education & 1 & 1.79 & 0 & 0.00 & 1 & 0.89 \\
\hline Pilipino & 3 & 5.36 & 2 & 3.57 & 5 & 4.46 \\
\hline Preschool & 1 & 1.79 & 24 & 42.86 & 25 & 22.32 \\
\hline Science & 1 & 1.79 & 4 & 7.14 & 5 & 4.46 \\
\hline Social Science & 1 & 1.79 & 0 & 0 & 1 & 0.89 \\
\hline $\begin{array}{l}\text { Teaching English as a Second } \\
\text { Language }\end{array}$ & 1 & 1.79 & 1 & 1.79 & 2 & 1.79 \\
\hline No Major & 41 & 73.22 & 27 & 48.22 & 68 & 60.72 \\
\hline \multicolumn{7}{|l|}{$\begin{array}{l}\text { Trainings Relative to Preschool } \\
\text { ucation }\end{array}$} \\
\hline 106 hours and above & 2 & 3.57 & 3 & 5.36 & 5 & 4.46 \\
\hline 71 - 105 hours & 3 & 5.36 & 1 & 1.79 & 4 & 3.57 \\
\hline $36-70$ hours & 8 & 14.29 & 6 & 10.71 & 14 & 12.50 \\
\hline 1 - 35 hours & 10 & 17.86 & 2 & 3.57 & 12 & 10.71 \\
\hline No training at all & 33 & 58.93 & 44 & 78.57 & 77 & 68.75 \\
\hline
\end{tabular}

The table uncovers that greater part of the respondents is females, with ages, which ranges from 20 to65 years of age. The majority of them are permanent in employment status. Majorities are also eligible, some from the teacher's examination, PBET and LET. On educational attainment, the preschool teachers from both public and private schools have adequate educational qualifications. Around 50 teachers have a major field of specialization in different areas but not preschool. Also, the table shows that there are more teachers from the private schools who have earned units in Preschool Education than in the public schools. In general, the public-school teachers do not have an adequate Preschool education while the private school teachers have an adequate number of units to teach preschool. 
Moreover, the training is not appropriate. The in-service training about early childhood education of both groups of teachers is less adequate. The public preschool teachers have teaching experience, which could be described as less adequate while the private preschool teachers have adequate teaching experience. In general, their teaching experience is less adequate.

LoCasale-Crouch (2007) say that relationship between instructor qualities and program attributes were not critical. In any case, the poorest quality profile was related with classroom destitution level, recommending that the kids who require the most astounding quality instructive encounters have instructors who are battling the most to give it.

\section{Table 2. Instructional Competence of Public and Private School Teachers}

\begin{tabular}{|c|c|c|c|c|}
\hline \multirow{2}{*}{ Indicators } & \multicolumn{2}{|c|}{ Public Schools } & \multicolumn{2}{|c|}{ Private Schools } \\
\hline & Mean & Description & Mean & Description \\
\hline \multicolumn{5}{|l|}{ A. Lesson Planning } \\
\hline $\begin{array}{l}\text { 1. Formulates/adopts objectives of lesson } \\
\text { plan }\end{array}$ & 4.98 & Outstanding & 4.00 & Very Satisfactory \\
\hline $\begin{array}{l}\text { 2. Selects content and prepare appropriate } \\
\text { instructional materials. }\end{array}$ & 4.80 & Outstanding & 4.20 & Very Satisfactory \\
\hline 3. Selects teaching methods/strategies & 4.65 & Outstanding & 4.01 & Very Satisfactory \\
\hline $\begin{array}{l}\text { 4. Relates new lesson with previous } \\
\text { knowledge/skills }\end{array}$ & 4.55 & Outstanding & 4.11 & Very Satisfactory \\
\hline 5. Provides appropriate motivation & 4.75 & Outstanding & 4.20 & Very Satisfactory \\
\hline 6. Presents and develops lessons & 4.60 & Outstanding & 3.91 & Very Satisfactory \\
\hline 7. Conveys ideas clearly & 4.55 & Outstanding & 3.85 & Very Satisfactory \\
\hline $\begin{array}{l}\text { 8. Uses the specialty of addressing to create } \\
\text { larger amount of considering }\end{array}$ & 4.70 & Outstanding & 3.92 & Very Satisfactory \\
\hline 9. Ensures pupils/students participation & 4.80 & Outstanding & 3.97 & Very Satisfactory \\
\hline 10. Addresses individual differences & 4.75 & Outstanding & 3.98 & Very Satisfactory \\
\hline 11. Shows mastery of the subject matter & 4.90 & Outstanding & 4.25 & Outstanding \\
\hline 12. Diagnoses learner's needs & 4.75 & Outstanding & 4.11 & Very Satisfactory \\
\hline 13. Evaluates learning outcomes & 4.80 & Outstanding & 4.12 & Very Satisfactory \\
\hline $\begin{array}{l}\text { 14. Surveys lesson to decide craved results } \\
\text { inside the allocated time. }\end{array}$ & 4.50 & Outstanding & 4.10 & Very Satisfactory \\
\hline 15. Maintains clean and orderly classroom & 4.60 & Outstanding & 4.21 & Outstanding \\
\hline $\begin{array}{l}\text { 16. Maintains classroom conducive to } \\
\text { learning }\end{array}$ & 4.60 & Outstanding & 3.70 & Very Satisfactory \\
\hline Aggregate Mean & 4.71 & Outstanding & 4.04 & Very Satisfactory \\
\hline
\end{tabular}




\section{B. Learner's Achievement}

1. Improves Learner's achievement level over pretest

4.38 Outstanding $\quad 4.00$ Very Satisfactory

Aggregate Mean $\quad 4.38$ Outstanding 4.00 Very Satisfactory

\section{School Home And Community} Involvement

1. Organizes and maintains functional Homeroom PTA

\begin{tabular}{|c|c|c|c|c|}
\hline IS Tu & 4.90 & Outstanding & 4.10 & Very Satisfactory \\
\hline $\begin{array}{l}\text { A meetings to } \\
\text { ss }\end{array}$ & 4.86 & Outstanding & 4.15 & Very Satisfactory \\
\hline olicies/laws & 4.80 & Outstanding & 4.23 & Very Satisfactory \\
\hline ity projects and & 4.84 & Outstanding & 3.90 & Very Satisfactory \\
\hline $\begin{array}{l}\text { tt of Parents in } \\
\text { attitudes }\end{array}$ & 4.85 & Outstanding & 4.20 & Very Satisfactory \\
\hline Aggregate Mean & 4.85 & Outstanding & 4.12 & Very Satisfactory \\
\hline Overall Mean & 4.65 & Outstanding & 4.05 & Very Satisfactory \\
\hline
\end{tabular}

2. Conduct Homeroom PTA meetings to report learner's progress

3. Disseminates School policies/laws program

4. Participates in Community projects and Civic Organization

5. Encourages involvement of Parents in school programs and attitudes

The table shows that the public schools obtained 4.71 weighted means while the private schools have 4.04 weighted mean in lesson planning and delivery. On learner's achievement, the public schools also excelled. This is also true for School, Home, and Community involvement. The average mean of 90.23 for the public preschool teachers is greater than the 78.47 mean of the private schools.

As per Jordan et al. (2009), pragmatic showing aptitudes comprise of abnormal amounts of understudy engagement given first classroom and time administration aptitudes; the capacity to platform discovering that is adjusted to understudies' present levels of seeing; psychologically captivating understudies in higher-arrange considering; and empowering and supporting achievement. 


\section{Table 3. Professional and Personal Characteristics} of Preschool Teachers

\begin{tabular}{|c|c|c|c|c|}
\hline \multirow[t]{2}{*}{ Indicators } & \multicolumn{2}{|r|}{$\begin{array}{l}\text { Public Schools } \\
\qquad(\mathrm{n}=38)\end{array}$} & \multicolumn{2}{|c|}{$\begin{array}{l}\text { Private Schools } \\
\qquad(\mathrm{n}=38)\end{array}$} \\
\hline & Mean & Description & Mean & Description \\
\hline 1. Decisiveness & 4.25 & Outstanding & 4.1 & Very Satisfactory \\
\hline 2. Honesty/Integrity & 3.95 & Very Satisfactory & 4.22 & Outstanding \\
\hline 3. Dedication/Commitment & 4.05 & Very Satisfactory & 4.1 & Very Satisfactory \\
\hline 4. Initiative/Resourcefulness & 4.1 & Very Satisfactory & 4.05 & Very Satisfactory \\
\hline 5. Courtesy & 4.05 & Very Satisfactory & 4.05 & Very Satisfactory \\
\hline 6. Human Relations & 3.95 & Outstanding & 4.25 & Outstanding \\
\hline 7. Leadership & 4.22 & Very Satisfactory & 3.95 & Very Satisfactory \\
\hline 8. Stress Tolerance & 3.89 & Very Satisfactory & 3.89 & Very Satisfactory \\
\hline 9. Fairness/Justice & 4.05 & Very Satisfactory & 4.05 & Very Satisfactory \\
\hline 10. Proper Attire/Good Grooming & 3.95 & Very Satisfactory & 3.8 & Very Satisfactory \\
\hline Overall Mean & 4.05 & Very Satisfactory & 4.05 & Very Satisfactory \\
\hline
\end{tabular}

Both gatherings of respondents were given exceptionally palatable execution appraisals on expert and individual attributes. They are rated very satisfactorily regarding the frequency by which the teachers demonstrate specified personal and professional characteristics.

The investigation of Brophy-Herb et al. (2007) uncovered that educators' sure evaluations of the preschooler's social fitness were anticipated by positive appraisals of classroom atmosphere and instructor practices. Active classroom atmosphere seemed to intercede the connection between educator practices and preschoolers' social ability.

Table 4. Punctuality and Attendance of the Preschool Teachers

\begin{tabular}{lcccc}
\hline \multirow{2}{*}{ Rating } & \multicolumn{2}{c}{ Public Schools } & \multicolumn{2}{c}{ Private Schools } \\
& Frequency & Weight & Frequency & Weight \\
\hline Outstanding & 21 & 5 & 20 & 5 \\
Very Satisfactory & 11 & 4 & 15 & 4 \\
Satisfactory & 2 & 3 & 3 & 3 \\
Fair & 0 & 2 & 0 & 2 \\
Unsatisfactory & 0 & 1 & 0 & 1 \\
$\quad$ Weighted Mean & $\mathbf{4 . 6 2}$ & & $\mathbf{4 . 4 5}$ & \\
$\quad$ Interpretation & Outstanding & & Outstanding \\
\hline
\end{tabular}


The table shows principals with excellent performance rated both groups of respondents. The teachers were seldom late and absent. School teachers are known to be the country developers. They are the savants and aides for the young understudies. The character and the identity of an educator extraordinarily impact the understudies whom they instruct. The learning of significance to time is the most extreme need in each one's life whether youthful or old. The propensity for dependability is required to be shaped at an incredibly young age. Propensities once framed whether great or terrible never fantastic.

Table 5. Significant Differences in Performance Among Preschool Teachers

\begin{tabular}{|c|c|c|c|c|c|c|c|c|}
\hline Performance in & $\begin{array}{l}\text { Respon- } \\
\text { dents }\end{array}$ & $\mathbf{n}$ & StDev & Mean & $\begin{array}{l}\text { Mean } \\
\text { Differ- } \\
\text { ence }\end{array}$ & $\begin{array}{l}\text { Com- } \\
\text { puted } t\end{array}$ & $\begin{array}{l}\text { Table } \\
\mathbf{t}\end{array}$ & $\begin{array}{l}\text { Deci- } \\
\text { sion }\end{array}$ \\
\hline \multirow[t]{2}{*}{$\begin{array}{l}\text { A. Professional } \\
\text { Preparation }\end{array}$} & $\begin{array}{l}\text { Public } \\
\text { Schools }\end{array}$ & 38 & 2.19 & 38.81 & 6.58 & 12.41 & 2.026 & $\begin{array}{l}\text { Ho is } \\
\text { rejected }\end{array}$ \\
\hline & $\begin{array}{l}\text { Private } \\
\text { Schools }\end{array}$ & 38 & 2.43 & 45.39 & & & & \\
\hline \multirow[t]{2}{*}{$\begin{array}{l}\text { B. Instructional } \\
\text { Competence }\end{array}$} & $\begin{array}{l}\text { Public } \\
\text { Schools }\end{array}$ & 38 & 3.29 & 90.47 & 3.73 & 12.13 & 2.026 & $\begin{array}{l}\text { Ho is } \\
\text { rejected }\end{array}$ \\
\hline & $\begin{array}{l}\text { Private } \\
\text { Schools }\end{array}$ & 38 & 0.92 & 86.74 & & & & \\
\hline \multirow[t]{2}{*}{$\begin{array}{l}\text { C. Professional } \\
\text { and Personal } \\
\text { Characteristics }\end{array}$} & $\begin{array}{l}\text { Public } \\
\text { Schools }\end{array}$ & 38 & 1.57 & 87.29 & 0.29 & 0.21 & 2.026 & $\begin{array}{l}\text { Ho is } \\
\text { rejected }\end{array}$ \\
\hline & $\begin{array}{l}\text { Private } \\
\text { Schools }\end{array}$ & 38 & 8.43 & 87.00 & & & & \\
\hline \multirow[t]{2}{*}{$\begin{array}{l}\text { D. Punctuality \& } \\
\text { Attendance }\end{array}$} & $\begin{array}{l}\text { Public } \\
\text { Schools }\end{array}$ & 38 & 1.08 & 78.95 & 5.05 & 21.04 & 2.026 & $\begin{array}{l}\text { Ho is } \\
\text { rejected }\end{array}$ \\
\hline & $\begin{array}{l}\text { Private } \\
\text { Schools }\end{array}$ & 38 & 0.99 & 84.00 & & & & \\
\hline \multirow[t]{2}{*}{$\begin{array}{l}\text { E. Overall Perfor- } \\
\text { mance }\end{array}$} & $\begin{array}{l}\text { Public } \\
\text { Schools }\end{array}$ & 38 & 4.95 & 84.24 & 0.48 & 1.00 & 2.026 & $\begin{array}{l}\text { Ho is } \\
\text { ac- } \\
\text { cepted }\end{array}$ \\
\hline & $\begin{array}{l}\text { Private } \\
\text { Schools }\end{array}$ & 38 & 3.68 & 83.76 & & & & \\
\hline
\end{tabular}

The table shows that both public and private preschool teachers are less adequately prepared in implementing the preschool program. The majority has not complied with the mandate of DepEd to earn at least 18 units of early childhood education. There is a significant difference in the professional preparation of the public and private preschool teachers with 
the private sector on the lead. The t-test of 12.41 rejects the hypothesis of no significance. The private school teachers are better in professional preparation than the public preschool teachers.

On instructional competence, the table reveals the difference in means of 3.73 for the Public schools generated a computed $t$ of 12.13 , which rejects the hypothesis of no significance. Therefore, the performance of the public preschool teachers in instructional competencies is greater than the public schools, so the public preschool teachers are better teachers than the private preschool regarding instruction skills based on the grades given by their direct supervisors.

On professional and personal characteristics, the hypothesis of no significance is accepted as true. Both groups obtained ratings, which are almost the same. The difference of 0.29 is not statistically significant.

On punctuality and attendance, the public preschool teachers are better regarding punctuality and attendance than the private preschool teachers. The mean difference of 5.05 for the public schools generated a 21.04 t-value, which rejects the hypothesis of no significance.

On the summary of overall performance, the table shows that there is no significant difference in the performance of all the three components. The hypothesis of no significance is accepted as true. This is demonstrated by the 0.48 differences in means, which is only very slight, and the computed t-value, which is only 1.0 , which is lesser than the table value 2.026 at .05 level of significance. Barnett (2003) says that the kinds of qualifications preschool teachers need, and reviews research indicating the relationship between teacher qualifications and program quality. The study concluded with policy recommendations require preschool teachers to have a four-year college degree and specialized training, design professional development programs enabling current early education teachers to acquire a four-year degree, and pay preschool teachers' salaries and benefits comparable to those of similarly qualified teachers in $\mathrm{K}-12$ education. 
Table 6. Relationship Between Profile and Performance Variables of Preschool Teachers

\begin{tabular}{|c|c|c|c|c|c|c|c|c|}
\hline \multirow[b]{2}{*}{ Variables } & \multicolumn{4}{|c|}{ Public Schools } & \multicolumn{4}{|c|}{ Private Schools } \\
\hline & $\begin{array}{l}\text { Chi- } \\
\text { square }\end{array}$ & $\mathbf{r}$ & $\mathbf{t}$ & Decision & $\begin{array}{l}\text { Chi- } \\
\text { square }\end{array}$ & $r$ & $\mathbf{t}$ & $\begin{array}{l}\text { Deci- } \\
\text { sion }\end{array}$ \\
\hline \multicolumn{9}{|l|}{ Profile and } \\
\hline $\begin{array}{l}\text { A. Instructional } \\
\text { Competence }\end{array}$ & 14.708 & 0.834 & 7.574 & $\begin{array}{l}\text { Ho is } \\
\text { rejected }\end{array}$ & 19.665 & 0.716 & 4.410 & $\begin{array}{l}\text { Ho is } \\
\text { rejected }\end{array}$ \\
\hline $\begin{array}{l}\text { B. Professional } \\
\text { \& Personal } \\
\text { Characteristics }\end{array}$ & 0.947 & 0.763 & 5.401 & $\begin{array}{l}\text { Ho is } \\
\text { rejected }\end{array}$ & 19.665 & 0.716 & 4.410 & $\begin{array}{l}\text { Ho is } \\
\text { rejected }\end{array}$ \\
\hline $\begin{array}{l}\text { C. Punctuality \& } \\
\text { Attendance }\end{array}$ & 16.542 & 0.804 & 6.612 & $\begin{array}{l}\text { Ho is } \\
\text { rejected }\end{array}$ & 11.804 & 0.904 & 11.495 & $\begin{array}{l}\text { Ho is } \\
\text { rejected }\end{array}$ \\
\hline
\end{tabular}

The table shows that all the performance indicators are greatly influenced by the professional preparation of the respondents. Their computed r's shows very significant relationships and all the computed t's rejected the hypothesis of no significance. Therefore, the professional preparations of the respondents are significantly related to their performance.

After effects of the investigation of Jeon et al. (2016) give essential data to use in early kid mind mediations and propose another approach toward more coordinated proficient improvement programs that cover both instructors' practices and employment demeanors. It proposes the requirement for new drilling frameworks that can be individualized given every educator's qualities and difficulties.

\section{CONCLUSIONS}

The researchers concluded that majority of the preschool teachers from both public and private schools are females, most of whom are in the young and middle age group; the majority are permanent in status and Civil Service eligible. The preschool teachers in public and private schools are adequately prepared in the general education curriculum for teachers but are not majors in preschool education nor have adequate units. The teachers in both groups have inadequate pre-service, in-service and special training. They have less adequate experience in the field of teaching preschoolers than the public preschool teachers.

The performance of the public and private preschool teachers is the same. There is no significant difference in the performance between the 
public and private preschool teachers. The professional preparation of the public and private school teachers are significantly related to their performance.

\section{RECOMMENDATIONS}

The researchers strongly recommend that the proposed training program for preschool teachers be implemented.

\section{TRANSLATIONAL RESEARCH}

The output of the study is translated into a proposed training program for preschool teachers to be used by DepEd and school administrators. The preparation program is intended to reinforce and upgrade the instructional ability, their professional and personal characteristics and punctuality and attendance of preschool teachers both in public and private schools offering pre-school education in the city of Cebu, Philippines. Also, this addresses what has been revealed as weak points in the study. It is an outgrowth of what is not fully developed in the study. The study revealed that the private school teachers obtained low-performance ratings in instructional competencies while the public-school teachers obtained low-performance ratings in punctuality and attendance. More improvements on these aspects will answer the clamor and challenge of the times for excellence and quality education which should start in pre-school education.

\section{LITERATURE CITED}

Bartlett, S., Hart, R., Satterthwaite, D., de la Barra, X., \&Missair, A. (2016). Cities for children: Children's rights, poverty, and urban management. Routledge. Retrieved March 2017 from https://goo.gl/ gLWYO3

Barnett, W. S. (2003). Better teachers, Better preschools: Student achievement linked to teacher qualifications. NIEER Preschool Policy Matters, Issue 2. Retrieved May 2017 from https://goo.gl/AVDqfE

Bernardo, A. B., \& Garcia, J. A. S. (2006). School improvement in a centralized educational system: The case of the Philippine basic 
educational system. School Improvement: International Perspectives, 227-244. Retrieved March 2017 from https://goo.gl/9wvMkB

Bonetti, S., Mindnich, J., \& Silva, A. (2016). 2016 California children's report card: A survey of kids' well-being \& a roadmap for the future. Children Now. Retrieved March 2017 from https://eric.ed.gov/?id=ED568674

Brophy-Herb, H. E., Lee, R. E., Nievar, M. A., \&Stollak, G. (2007). Preschoolers' social competence: Relations to family characteristics, teacher behaviors, and classroom climate. Journal of Applied Developmental Psychology, 28(2), 134-148. Retrieved May 2017 from https://goo.gl/riKLi4

Doyle, O., Harmon, C. P., Heckman, J. J., \& Tremblay, R. E. (2009). Investing in early human development: Timing and economic efficiency. Economics \& Human Biology, 7(1), 1-6. Retrieved April 2017 from https://goo.gl/ zkmS8z

Early, D. M., Maxwell, K. L., Burchinal, M., Alva, S., Bender, R. H., Bryant, D., ... \& Henry, G. T. (2007). Teachers' education, classroom quality, and young children's academic skills: Results from seven studies of preschool programs. Child development, 78(2), 558-580. Retrieved April 2017 from https://goo.gl/icOJpm

Eichner, J. C., Groark, C., \&Palmov, O. (2011). Early intervention: International policies and programs. Early childhood intervention: Shaping the future for children with special needs and their families, 1 , 37-70. Retrieved April 2017 from https://goo.gl/xG7o5J

Haq, Z. I. A., Alfilfili, H. H., \&Joradan, J. (2015). The efficiency of an educational program based Montessori curriculum in developing logical thinking in kindergarten children. European Journal of Research and Reflection in Educational Sciences Vol, 3(1).Retrieved April 2017 from https://goo.gl/Nk5Pud

Irwin, L. G., Siddiqi, A., \&Hertzman, C. (2007). Early child development: A powerful equalizer. Final report to the WHO Commission on Social Determinants of Health, Geneva. Retrieved April 2017 from https://goo. gl/twUTN5 
Jeon, L., Buettner, C. K., \&Hur, E. (2016). Preschool teachers' professional background, process quality, and job attitudes: A person-centered approach. Early Education and Development, 27(4), 551-571. Retrieved May 2017 from https://goo.gl/9i3AeP

Jordan, A., Schwartz, E., \&McGhie-Richmond, D. (2009). Preparing teachers for inclusive classrooms. Teaching and teacher education, 25(4), 535542.Retrieved May 2017 from https://goo.gl/OeRfSu

Kaga, Y., Bennett, J., \& Moss, P. (2010). Caring and Learning together: A cross-national study on the integration of early childhood care and education within education. UNESCO. Retrieved April 2017 from https:// goo.gl/buL8Bs

Kolker, C. (2011). The immigrant advantage: What we can learn from newcomers to America about health, happiness, and hope. Simon and Schuster. Retrieved April 2017 from https://goo.gl/8lkz51

Lapus, S. J. A. (2008). The education system facing the challenges of the 21st century. Age, 3(4), 5. Retrieved March 2017 from https://goo.gl/ THH7UQ

LoCasale-Crouch, J., Konold, T., Pianta, R., Howes, C., Burchinal, M., Bryant, D., ... \&Barbarin, O. (2007). Observed classroom quality profiles in state-funded pre-kindergarten programs and associations with teacher, program, and classroom characteristics. Early Childhood Research Quarterly, 22(1), 3-17. Retrieved May 2017 from https://goo. gl/X8bwkV

Lupien, S. J., McEwen, B. S., Gunnar, M. R., \& Heim, C. (2009). Effects of stress throughout the lifespan on the brain, behaviour, and cognition. Nature Reviews Neuroscience, 10(6), 434-445. Retrieved April 2017 from https://goo.gl/M4CJYn

Luz, J. M. (2009). The challenge of governance in a large bureaucracy (Department of Education): Linking governance to performance in an under-performing sector. Philippine HDN (Human Development Network) Report 2008, 9. Retrieved March 2017 from https://goo.gl/ $\mathrm{N} 1 \mathrm{eTba}$ 
Maca, M., \& Morris, P. (2012). The Philippines, the East Asian developmental states, and education: A comparative analysis of why the Philippines failed to develop. Compare: A Journal of Comparative and International Education, 42(3), 461-484. Retrieved March 2017 from https://goo. gl/9tJ2al

Maggi, S., Irwin, L. J., Siddiqi, A., \&Hertzman, C. (2010). The social determinants of early child development: An overview. Journal of Paediatrics and Child Health, 46(11), 627-635. Retrieved April 2017 from https://goo.gl/ytO1N8

Manuel, M. F., \& Gregorio, E. B. (2011). Legal frameworks for early childhood governance in the Philippines. International Journal of Child Care and Education Policy, 5(1), 65-76. Retrieved March 2017 from https://goo. $\mathrm{gl} / 2 \mathrm{Up} 1 \mathrm{P}$

Marmot, M., \& Bell, R. (2012). Fair society, healthy lives. Public health, 126, S4-S10. Retrieved April 2017 from https://goo.gl/dBvsDE

Monsalve, A. O. (2016). The state of teacher education in Region V: Policy implication. The Contribution of Education Institution to ASEAN Economic Community, 23. Retrieved March 2017 from https://goo.gl/ TFO2c4

Taylor, J. M. B. (2016). Communication between educators and parents in Title I elementary schools. Retrieved March 2017 from https://goo. gl/4IX08Y

Thom-Otuya, B. E. (2012). Leadership and followership: Essential factors for National Development and Achievement of Organizational Goals. Mediterranean Journal of Social Sciences, 3(15). Retrieved March 2017 from https://goo.gl/pjyXoW

Twyman, C. (2016). Supporting prekindergarten teachers through appropriate professional development practices. Retrieved March 2017 from http://stars.library.ucf.edu/etd/5047/ 
Vesely, C. K. (2013). Low-income African and Latina immigrant mothers' selection of early childhood care and education (ECCE): Considering the complexity of cultural and structural influences. Early Childhood Research Quarterly, 28(3), 470-486. Retrieved April 2017 from https:// goo.gl/q35WKP

Visse, K. (2016). Closing the gap: Impact of instruction on students not ready for kindergarten (Doctoral dissertation, Northern Kentucky University). Retrieved March 2017 from https://goo.gl/r5ITbD

Yoshikawa, H., \&Kabay, S. (2015). The evidence base on early childhood care and education in global contexts. Retrieved April 2017 from https:// goo.gl/TPvu3V

Yunusa, S. U. A. (2016). An appraisal of Child-Friendly Status (CFS) of Early Childhood Care Education (ECCE) schools in Niger State (Doctoral dissertation). Retrieved April 2017 from https://goo.gl/CQEdhB 